\title{
1
}

\section{Introduction: International Interdependencies and the Impact on Social Policies}

\section{Frank Nullmeier, Delia González de Reufels, and Herbert Obinger}

In recent years, social policy research has undergone a vast array of farreaching changes. Perhaps the most important change concerns the scope of research, which is no longer exclusively focused on the nation state. In the not-so-distant past, "(...) to study social policy was to start with the nation" (Rodgers 2014, 302). This quote could be further amended by pointing out that social policy research also was mainly concerned with Western nations. While this can hardly be surprising given that the welfare state as such is a European "invention" and can be considered a child of the nation state and the Industrial Revolution (Flora 1986a, XII), other factors come into play as well. Although the strong focus on the nation as the main unit of analysis is reasonable, as it is the state's prerogative to enact and implement welfare legislation in a given territory, this is only one side of the story. From the very onset of social policy development, this process was embedded in and to a large extent the result of

F. Nullmeier $(\bowtie) \bullet$ D. González de Reufels $\bullet$ H. Obinger University of Bremen, Bremen, Germany e-mail: Frank.Nullmeier@uni-bremen.de; dgr@uni-bremen.de; herbert.obinger@uni-bremen.de 
influences that lay beyond the nation and its specific contexts: social policy-makers did not act in splendid isolation. In addition to the fierce domestic struggles over social policy, their decisions were framed by various inter- and transnational influences. Even during the formative period of the welfare state, intensive cross-border knowledge transfers already enabled policy-makers to learn about foreign welfare legislation (Rodgers 1998). Nineteenth-century policy-makers were also concerned about the impact of social policy on their nations' economic competitiveness when they discussed and drafted early welfare reforms during the first wave of economic globalisation that lasted until 1914. Moreover, ever-increasing military rivalries and power ambitions of nation states in the Age of Imperialism left their imprint on social policy. Worries about low birth rates or the physical fitness of soldiers vis-à-vis the alleged enemy sparked or bolstered welfare reforms in areas such as labour protection, child welfare and family policy in the run-up to war.

In 1914, war eventually became a terrible reality, only to be followed by yet another even more devastating war in 1939. Two world wars and their political and socio-economic aftershocks were a watershed for welfare state development in several respects: they entailed welfare cutbacks but also triggered a massive expansion of social policy in the immediate post-war period in response to the tremendous social needs generated by the horrors of war and demobilisation (Obinger et al. 2018). In a similar vein, the Bolshevik Revolution in Russia and the Great Depression sent shock waves across the globe that affected social policy in various but ambiguous ways. International organisations such as the International Labour Organization and the World Health Organization, established after armistice and particularly after the Second World War, gave rise to ever-increasing intergovernmental social policy cooperation worldwide and provided the basis for global shifts in social policy, but also demonstrated the limits of international support or steering of an expansion of social policy (Deacon 2013; Maul 2019; Seekings 2019).

Moreover, the two world wars fundamentally changed the international economic order. Whereas the Great War and the Great Depression led to economic deglobalisation and growing trade protectionism, the post-1945 economic order created in Bretton Woods in 1944 paved the way for the restoration of international trade and economic cooperation 
that underpinned a massive expansion of the Western welfare state (Wilensky 1975; Esping-Andersen 1990; Nullmeier and Kaufmann 2021). The so-called Golden Age of the Western welfare state, in other words, the period stretching from 1945 to the mid-1970s, largely coincided with the Cold War and the concomitant bipolar regime competition. The two oil shocks of the 1970s brought the exceptional growth of the Western welfare state and the underlying post-war Keynesian compromise to an end. The response to stagflation was a shift towards supplyside oriented economic policies with a view to stimulating growth and employment. This neoliberal turn was not least promoted by international organisations such as the Organisation for Economic Co-operation and Development, and under the auspices of the International Monetary Fund and the World Bank spread rapidly across the globe. In the 1990s, deregulation of trade barriers and financial market integration unleashed a third wave of economic globalisation that has exposed the now mature Western welfare states to new external vulnerabilities, while the progress of European integration - another repercussion of warfare-has undercut the autonomy of European welfare states and re-drawn the boundaries of welfare (Ferrera 2002). In addition, the collapse of the Eastern Bloc delegitimised the welfare state as a third way between Soviet collectivism and unfettered capitalism.

Inter- and transnational influences on social protection are even more pronounced and relevant in the Global South (Abu Sharkh and Gough 2010). Just as in the Northern hemisphere, these influences shaped welfare provision from the very start. While some influences such as the two world wars, bipolar system competition, economic depression or pandemics affected the Northern and Southern hemispheres in similar ways, other factors have been more confined to the Global South. For example, missionaries and churches were early providers of welfare in various fields such as health and basic education. Furthermore, most countries in the Global South have a colonial past that has affected social protection deeply but, contingent upon the imperial power, has done so in different ways (Midgley and Piachaud 2011; Schmitt 2015, 2020). While education and health continue to be important fields of international social policy intervention, the measures have become more varied. Here, development aid has played an important role: monetary and technical 
support provided by international and non-governmental organisations, private foundations or donor countries plays an essential role in designing, financing and providing welfare benefits, while remittances sent by migrants make up a significant share of the gross domestic product in many low-income countries and enable their recipients, usually their relatives, to pay for services that the national welfare system does not provide (Schmitt 2020). Likewise, the new social policy instruments of conditional cash transfers (CCTs) such as "Oportunidades" in Mexico and "Bolsa Família" in Brazil have provided the push for diffusion in Latin America and in other regions of the world (Barrientos 2013; Leisering 2019). Social policy can be driven by migration flows when workers from the Global North transport ideas from the labour movement to the Global South. But it can also trigger migratory movements from South and East to North, for example in the care and health sector (Yeates and Pillinger 2019).

Over the past two decades or so, scholars have begun to study these inter- and transnational impacts on social policy more systematically. The "transnational turn" in historiography (e.g. Rodgers 1998; Conrad 2011; Kettunen and Petersen 2011), the new perspectives of global history ( $\mathrm{Hu}$ and Manning 2010), transnational social policy (Orenstein 2008; Gingrich and Köngeter 2017), global social policy (Deacon 2007; Yeates 2014; Kaasch and Stubbs 2014) and diffusion research in the social sciences (Kuhlmann et al. 2020) have contributed to transcending the nation as the unit of analysis and to studying the manifold relations and interdependencies between countries and societies. Moreover, a growing volume of scholarly work examines social policy and the history of social protection in the Global South or even across the globe (Haggard and Kaufman 2008; Huber and Stephens 2012; Finkel 2019; Hill and Irving 2020; Leisering 2021; Tajmazinani 2021). These new perspectives on social policy have underscored the importance of a global flow of ideas and concepts in a variety of policy fields, some of which have become global spheres of intervention for states and international organisations (Packard 2016). At a time when groups of professionals and expert networks assessed national and international fields such as health (Cueto and Palmer 2015; Akami 2017), the transfer of European social policy ideas around the globe impacted modernisation and social policy reform. 
Historical studies have provided insights into why and how Asian countries imported European and US concepts and ideas and adapted them to national needs (Nishizawa 2014). But imperial contexts did not exert a unidirectional influence: New Zealand's pension scheme for example was decisive for the remodelling of the Old Age Pensions Bill in Britain in 1908 (Rogers 2014).

This volume presents the most recent work on these issues from German social policy research. Despite progress and fascinating scholarly work sparked off by these approaches, the mainstream of comparative welfare state research in Germany lagged behind these developments. While German scholars have conducted cutting-edge research with regard to the development of Western welfare states (e.g. Alber 1982; Schmidt 1982; Flora 1986b) and EU social policy (Leibfried and Pierson 1995), social protection in the Global South was with few exceptions neglected in scholarly work for a long time. Systematic research on social policy in the Global South did not begin in Germany until the Bielefeld FLOOR project (Leisering 2019). To deepen and broaden this research approach in Germany, the German Research Foundation (DFG) is funding the Collaborative Research Center (CRC) "Global Dynamics of Social Policy" based at the University of Bremen (https://www.socialpolicydynamics.de/en/). Starting in 2018, more than eighty junior and senior scholars from various disciplines working in sixteen different projects are studying the development of state-run social policy across the globe from the 1880 s to the present. The CRC's central goal is to describe and explain the development dynamics of social policy within their international contexts, worldwide interrelations and the interaction with national conditions. In analytical terms, the CRC's objective is to replace the nationcentred orientation of social policy research with an interdependency-centred approach that integrates the well-known domestic determinants of social policy into the context of transregional and international interrelations. Once the national container is left behind, cross-border interrelations(de-)colonisation, war, trade and financial relations, migration flows, transnational communication and information exchange, international organisations and international agreements-move to the centre of social policy analysis. It is only from the interaction of national conditions with horizontal and vertical international interrelations that the 
developmental trajectories in social policy can be explained appropriately from a global and historical perspective. To that end, the CRC is also compiling a comprehensive social policy database-the Global Welfare State Information System (WeSIS) that will map social policy developments across the globe.

\section{Scope and Content of the Book}

This volume presents first preliminary findings from the sixteen research projects of the CRC. It consists of thirty-nine short essays that exemplify how the interplay between inter- and transnational relations and domestic factors have shaped the dynamics of social policy in various parts of the world and at different points in time.

The volume is divided into four parts that are concerned with a particular type of cross-border interrelation, and each part features a short thematic introduction. More specifically, the four parts examine the impact on social policy of violence (Part I), international organisations (Part II), trade relations and economic crises (Part III) ideas, and expert networks and migration (Part IV). Although each part of this volume highlights a specific type of inter- or transnational interdependence, the individual articles take into account that more than one type of interdependence can be present and effective at the same time.

The essays shed light on particular historical episodes in the development of social policy that represent only a very small and necessarily selective part of the global development of social protection. They are interested in studying specific cases and focus on very specific time frames that range from the late nineteenth to the more recent twentieth century.

We have named these short essays "short histories" because they are a mixture of the literal form of a "short story" and the far-reaching ambition of writing a comprehensive "short history" of social policy, which is beyond the scope of this book. The aim is much more modest as the chapters illuminate selective episodes of social policy development in various world regions at different points in time with a view to demonstrating the importance of inter- and transnational influences. They all rely on an analytical framework that brings inter- and transnational 
impacts on social policy to the foreground without neglecting national conditions.

Acknowledgements This chapter is a product of the research conducted in the Collaborative Research Centre "Global Dynamics of Social Policy" at the University of Bremen. The centre is funded by the Deutsche Forschungsgemeinschaft (DFG, German Research Foundation)—project number 374666841-SFB 1342.

\section{References}

Abu Sharkh, Miriam, and Ian Gough. 2010. Global Welfare Regimes. A Cluster Analysis. Global Social Policy 10 (1): 27-58.

Akami, Tomoko. 2017. Imperial Polities, Intercolonialism, and the Shaping of Global Governing Norms: Public Health Expert Networks in Asia and the League of Nations Health Organization, 1908-37. Journal of Global History 12: 4-25.

Alber, Jens. 1982. Vom Armenhaus zum Wohlfahrtsstaat. Analysen zur Entwicklung der Sozialversicherung in Westeuropa. Frankfurt/New York: Campus.

Barrientos, Armando. 2013. Social Assistance in Developing Countries. Cambridge: Cambridge University Press.

Conrad, Christoph. 2011. Social Policy History after the Transnational Turn. In Beyond Welfare State Models. Transnational Historical Perspectives on Social Policy, ed. Pauli Kettunen and Klaus Petersen, 218-240. Cheltenham: E. Elgar. Cueto, Marcos, and Steven Palmer. 2015. Medicine and Public Health in Latin America. A History. Cambridge: Cambridge University Press.

Deacon, Bob. 2007. Global Social Policy \& Governance. London: Sage. 2013. Global Social Policy in the Making. The Foundations of the Social Protection Floor. Bristol, Chicago: Policy Press.

Esping-Andersen, Gøsta. 1990. The Three Worlds of Welfare Capitalism. Cambridge: Polity.

Ferrera, Maurizio. 2002. The Boundaries of Welfare. European Integration and the New Spatial Politics of Social Protection. Oxford: Oxford University Press.

Finkel, Alvin. 2019. Compassion. A Global History of Social Policy. London: Red Globe Press. 
Flora, Peter. 1986a. Introduction. In Growth to Limits. The Western European Welfare States since World War II, vol.1, ed. Peter Flora, XII-XXXVI. New York/ Berlin: De Gruyter.

, ed. 1986b. Growth to Limits. The Western European Welfare States since World War II. New York/Berlin: De Gruyter.

Gingrich, Luann Good, and Stefan Köngeter, eds. 2017. Transnational Social Policy. Social Welfare in a World on the Move. London: Routledge.

Haggard, Stephan, and Robert R. Kaufman. 2008. Development, Democracy, and Welfare States: Latin America, East Asia, and Eastern Europe. Princeton, NJ: Princeton University Press.

Hill, Michael, and Zoe Irving, eds. 2020. Exploring the World of Social Policy. An International Approach. Bristol: Policy Press.

$\mathrm{Hu}$, Aiqu, and Patrick Manning. 2010. The Global Social Insurance Movement since the 1880s. Journal of Global History 5: 125-148.

Huber, Evelyne, and John D. Stephens. 2012. Democracy and the Left: Social Policy and Inequality in Latin America. Chicago, London: The University of Chicago Press.

Kaasch, Alexandra, and Paul Stubbs, eds. 2014. Transformations in Global and Regional Social Policies. Houndmills: Palgrave.

Kettunen, Pauli, and Klaus Petersen, eds. 2011. Beyond Welfare State Models: Transnational Historical Perspectives on Social Policy. Cheltenham: E. Elgar.

Kuhlmann, Johanna, Delia González de Reufels, Klaus Schlichte, and Frank Nullmeier. 2020. How Social Policy Travels: A Refined Model of Diffusion. Global Social Policy 20 (1): 80-96.

Leibfried, Stephan, and Paul Pierson, eds. 1995. European Social Policy: Between Fragmentation and Integration. Washington, DC: The Brookings Institution. Leisering, Lutz. 2019. The Global Rise of Social Cash Transfers. How States and International Organizations Constructed a New Instrument for Combating Poverty. Oxford: Oxford University Press.

- ed. 2021. Hundred Years of Social Protection. The Changing Social Question in Brazil, India, China, and South Africa. Cham: Palgrave.

Maul, Daniel. 2019. The International Labour Organization. 100 Years of Global Social Policy. Berlin, Geneva: De Gruyter Oldenbourg and ILO.

Midgley, James, and David Piachaud, eds. 2011. Colonialism and Welfare. Social Policy and the British Imperial Legacy. Cheltenham: Edward Elgar.

Nishizawa, Tamotsu. 2014. The Economics of Social Reform Across Borders: Fukuda's Welfare Economic Studies in International Perspective. Journal of Global History 9: 232-253. 
Nullmeier, Frank, and Franz-Xaver Kaufmann. 2021. Post-War Welfare State Development. The Golden Age. In In The Oxford Handbook of the Welfare State, ed. Daniel Beland, Kimberly Morgan, Herbert Obinger, and Christopher Pierson. Oxford: Oxford University Press.

Obinger, Herbert, Klaus Petersen, and Peter Starke, eds. 2018. Warfare and Welfare. Military Conflict and Welfare State Development in Western Countries. Oxford: Oxford University Press.

Orenstein, Mitchell. 2008. Privatizing Pensions. The Transnational Campaign for Social Security Reform. Princeton: Princeton University Press.

Packard, Randall M. 2016. A History of Global Health. Interventions into the Lives of Other Peoples. Baltimore: Johns Hopkins University Press.

Rodgers, Daniel T. 1998. Atlantic Crossings: Social Politics in a Progressive Age. Cambridge, MA: Harvard University Press.

- 2014. Bearing Tales: Networks and Narratives in Social Policy Transfer. Journal of Global History 9: 301-313.

Rogers, Edmund. 2014. A 'Most Imperial' Contribution: New Zealand and The Old Age Pensions Debate in Britain, 1898-1912. Journal of Global History 9: 189-207.

Schmidt, Manfred G. 1982. Wohlfahrtsstaatliche Politik unter bürgerlichen und sozialdemokratischen Regierungen. Frankfurt am Main: Campus.

Schmitt, Carina. 2015. Social Security Development and the Colonial Legacy. World Development 70: 332-342. ed. 2020. From Colonialism to International Aid. External Actors and Social Protection in the Global South. Cham $(\mathrm{CH})$ : Palgrave Macmillan.

Seekings, Jeremy. 2019. The Limits to 'Global' Social Policy: The ILO, the Social Protection Floor and the Politics of Welfare in Southern Africa. Global Social Policy 19 (1-2): 139-158.

Tajmazinani, Ali Akbar, ed. 2021. Social Policy in the Islamic World. Cham: Palgrave.

Wilensky, Harold L. 1975. The Welfare State and Equality. Berkeley: University of California Press.

Yeates, Nicola, ed. 2014. Understanding Global Social Policy. Bristol: Policy Press. Yeates, Nicola, and Jane Pillinger. 2019. International Health Worker Migration and Recruitment: Global Governance, Politics and Policy. London, New York: Routledge. 
Open Access This chapter is licensed under the terms of the Creative Commons Attribution 4.0 International License (http://creativecommons.org/licenses/ by/4.0/), which permits use, sharing, adaptation, distribution and reproduction in any medium or format, as long as you give appropriate credit to the original author(s) and the source, provide a link to the Creative Commons licence and indicate if changes were made.

The images or other third party material in this chapter are included in the chapter's Creative Commons licence, unless indicated otherwise in a credit line to the material. If material is not included in the chapter's Creative Commons licence and your intended use is not permitted by statutory regulation or exceeds the permitted use, you will need to obtain permission directly from the copyright holder.

(c) 